\title{
Maps of current semi-natural forest ecosystem types of Germany and the Kellerwald National Park (Hesse, Germany)
}

\author{
Stefan Nickel ${ }^{1}$ (D) - Winfried Schröder ${ }^{1}$ - Martin Jenssen ${ }^{2}$ \\ Received: 28 March 2018 / Accepted: 29 May 2019 / Published online: 24 June 2019 \\ (C) INRA and Springer-Verlag France SAS, part of Springer Nature 2019
}

\begin{abstract}
- Key message A spatial explicit approach coping with potential modifications in ecological structures and functions of forests due to climate change and atmospheric deposition was developed for Germany (Jenssen et al. 2013; Schröder et al. in Sci Total Environ 521-522:108-122, 2015). As a result, two maps of current semi-natural forest ecosystem types of Germany (1991-2010) and the Kellerwald National Park (2001-2010) are presented. The data provided (Nickel et al. 2018) are accessible at https://doi.org/10. 1594/PANGAEA.887305 and comprise 120 ecosystem types (89 near-natural ecosystems, 31 cultivated ecosystems) covering $27 \%$ of Germany's territory and, respectively, 17 forest types (12 near-natural, 5 cultivated) covering $86 \%$ of the National Park area. The data are in particular of relevance for spatial ecology and conservation purposes. Associated metadata is available at https:// agroenvgeo.data.inra.fr/geonetwork/srv/fre/catalog.search\#/metadata/b5e5d76f-6176-4d6d-9089-a607bc8a4076
\end{abstract}

Keywords Accuracy · Ecological indicators · GiS mapping · Ground-truthing · Quality control · Ecosystem types

\section{Background}

For Germany, an integrative approach for ecosystem assessment was developed that can cope with potential modifications in ecological structures and functions due to climate change and atmospheric nitrogen deposition (Schröder et al. 2015). An indispensable precondition for these assessments and projections was the classification of forest types and their mapping at different scales. According to Hofmann (1997), ecosystem types should be classified as entities characterized by certain homogeneity of significant features of their structures and

\section{Contributions of the co-authors}

Winfried Schröder headed the investigation and drafted the manuscript. Stefan Nickel developed and applied data evaluation strategies and conducted the ground truthing. Martin Jenssen developed the forest classification and contributed to the writing of the manuscript.

Handling Editor: Marianne Peiffer

Stefan Nickel

stefan.nickel@uni-vechta.de

Winfried Schröder

winfried.schroeder@uni-vechta.de

1 Landscape Ecology, University of Vechta, Vechta, Germany

2 Institute of Forestry Eberswalde, Bad Freienwalde, Germany functions. Accordingly, ecosystem types were categorized using data collected for 21,600 forest sites across Germany during the years 1961-1990. One hundred eighty different Ecosystem Types (EsT), 135 near-natural forest ecosystem types and 45 cultivated forest ecosystem types were classified and detailed quantitatively by Jenssen et al. (2013). Focusing on forest ecosystems, two maps of Current semi-natural Ecosystem Types (cEsT) build up under current land use conditions were derived from available data: (1) cEsT of Germany (1:500,000 equivalent scale; 1991-2010) (Jenssen et al. 2013) and (2) cEsT in the Kellerwald National Park (1:25,000 equivalent scale; 2001-2010) (Schröder et al. 2017a). With regard to their data quality and reusability, both maps were validated by example of vegetation data collected within Germany and the Kellerwald National Park (Hesse, Germany).

\section{Methods}

cEsT in Germany Linking the potential natural vegetation (pnV) map (Suck et al. 2010) with the dominating ecosystem type that is spatially included in the $\mathrm{pnV}$ complexes within a geographic information system (GIS) and applying a vegetation similarity measure according to Jenssen (2010) enabled mapping of the potential natural ecosystem types (pEsT) across Germany. The method is completely explained by 
Jenssen et al. (2013). Here, as an example, according to Suck et al. (2010), pnV unit M31 "Asperulo-Fagetum beech forests in complex with Luzulo-Fagetum beech forests" was assigned to "Asperulo-Fagetum beech forests". Thus, pEsT "Loamy mull beech forests" (code Eb-5n-D1) was assigned to M31 as the dominating ecosystem type". Then, the respective map was connected with maps of dominant tree species distribution (EFDAC 2011) and actual land use derived from Corine Land Cover 2000 (CLC2000, EEA 2010) in a GIS, enabling to identify and map current ecosystem types (cEsT) at a spatial resolution equivalent to a map scale of 1:500,000 by application of conditional statements to the aforementioned geodata as described in Fig. 1. For deciding, whether or not the dominating land use category with the greatest area is consistent with pEsT, the map of potential natural ecosystem types has been intersected with CLC2000 land use categories 311 (broadleaved forest), 312 (coniferous forest), 313 (mixed forest), 321 (natural grasslands), 322 (moors and heathland), 324 (transitional woodland-shrub), 331 (beaches, dunes, sands), 332 (bare rocks) and 333 (sparsely vegetated areas). Tree species coincidence was determined by deciding whether or not dominant tree species in the $1 \mathrm{~km} \times 1 \mathrm{~km}$ grid of EFDAC (2011) matches the main tree species of the ecosystem types as described by Jenssen et al. (2013). Tree species coincidence was determined by deciding whether or not dominant tree species in the $1 \mathrm{~km} \times 1 \mathrm{~km}$ grid of EFDAC (2011) matches the main tree species of the (near- and semi-natural and, respectively, cultivated) ecosystem types (EsT) as described by Jenssen et al. (2013). EsT is a common term for pEsT and cEsT. pEsT encompass merely "near- and semi-natural EsT", whilst cEsT could be "near- and semi-natural EsT" or "cultivated EsT". The if-then-statement in Fig. 1 refers exclusively to "near- and semi-natural EsT", whereby TRUE will lead to the following: $\mathrm{cEsT}=\mathrm{pEsT}$. The elseif-then-statement refers to "cultivated EsT" using the main tree species of the cultivated ecosystem types as described by Jenssen et al. (2013).

The quality of the German-wide forest-type map marked with cEsT in Fig. 1 (Jenssen et al. 2013; Schröder et al. 2017a) was determined according to EN ISO 19157 (ISO 2013) with regard to the criteria listed in Table 1. In the following, the methods to examine the accuracy of contents and geographic position will be dealt with.

The measurement of the absolute accuracy of position of geometric elements was performed through comparison with respective data from the Base Digital Landscape Model ATKIS of Hesse. The geometric accuracy of this model accounts for $\pm 3 \mathrm{~m}$ (HVBG 2014).

All deciduous, coniferous and mixed forests of ATKISDLM were labelled as forest and spatially overlaid with the forest-type map. The distances between selected points of boundary lines of 400 obviously identical polygons depicting the spatial extension of a given ecosystem type and, respectively, a given forestry land use class from the ATKIS-DLM were determined. The samples were not randomly generated, but selected by the user, whereby the apparently largest distance between the borders of the polygons was taken. For each of the 400 selected objects, exactly one distance measurement was performed. To this end, each 200 points was selected from the ATKIS-DLM used as reference system located inside and outside of the objects depicted in the forest-type map. Cases with differences exceeding the threefold standard deviation (outliers) were excluded from the data set. The statistical distribution of the distance values was visualized as histograms and quantilequantile plots (QQ-Plots) and analysed for normal distribution

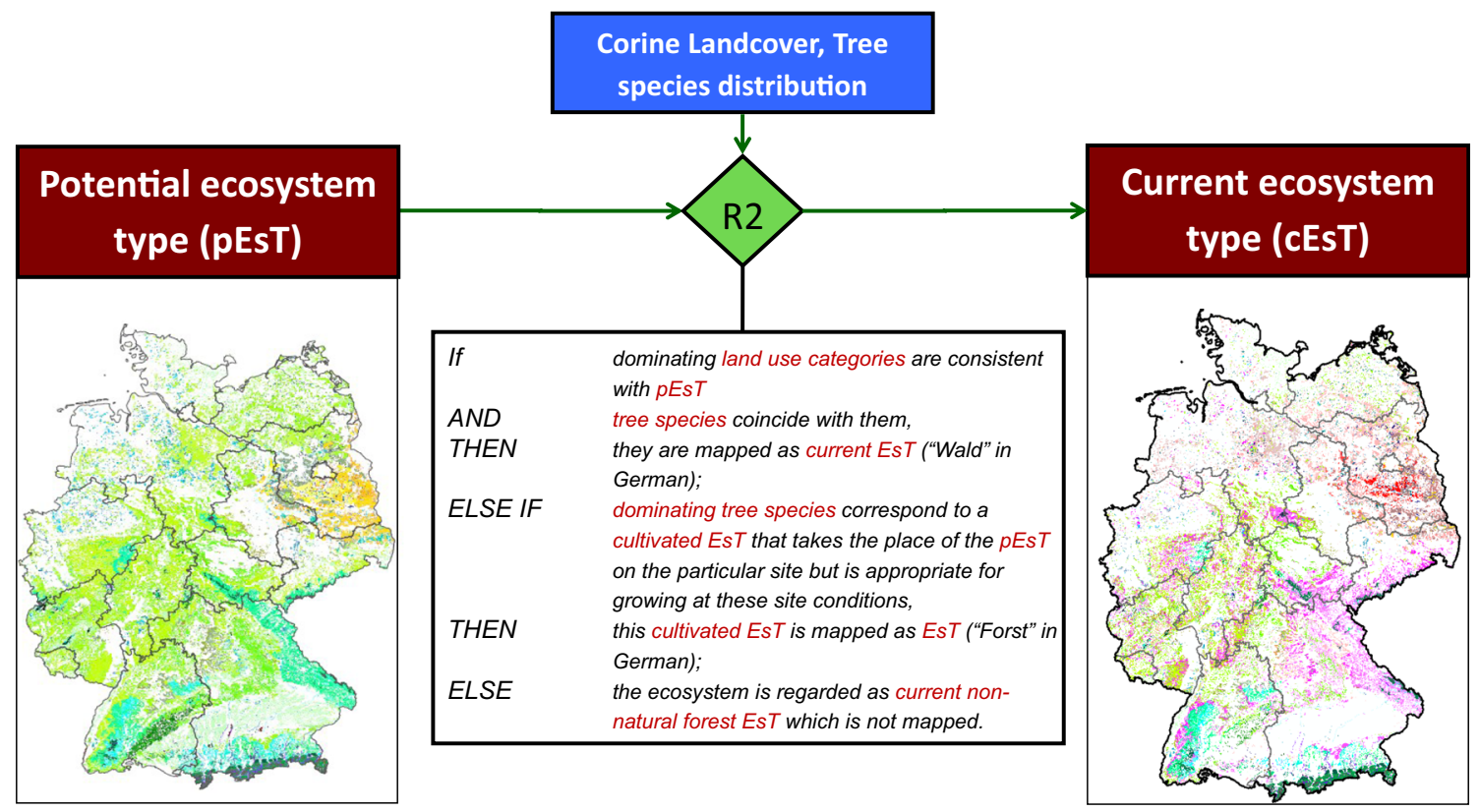

Fig. 1 Rule-based mapping of current forest ecosystem types in Germany 
Table 1 Quality characteristics for maps according to ISO (2013) and their application on cEsT data

\begin{tabular}{|c|c|c|c|}
\hline Quality element & Sub-element & Measure & Method \\
\hline $\begin{array}{l}\text { (1) Positional } \\
\text { accuracy }\end{array}$ & $\begin{array}{l}\text { Absolute or external } \\
\text { accuracy }\end{array}$ & Standard deviation $( \pm \mathrm{m})$ & $\begin{array}{l}\text { Determining distances between selected points of boundary } \\
\text { lines of cEsT and geo-objects from ATKIS-DLM that } \\
\text { represent broad-leaved forests, mixed forests and } \\
\text { coniferous forests (= relative accuracy) under consideration } \\
\text { of their known positional accuracies and error propagation } \\
\text { (= absolute accuracy) }\end{array}$ \\
\hline \multirow[t]{2}{*}{$\begin{array}{l}\text { (2) Thematic } \\
\text { accuracy }\end{array}$} & \multirow[t]{2}{*}{$\begin{array}{r}\text { Classification } \\
\text { correctness }\end{array}$} & $\begin{array}{l}\text { Percentage of objects, where cEsT occurs as } \\
\text { the predominant ecosystem type }\end{array}$ & $\begin{array}{l}\text { Comparing cEst with field data (FFH habitats and biotopes } \\
\text { in Hesse) }\end{array}$ \\
\hline & & $\begin{array}{l}\text { Percentage of objects, where cEsT occurs } \\
\text { as ecosystem type }\end{array}$ & $\begin{array}{l}\text { Comparing cEst with field data (vegetation samplings in } \\
\text { Germany) }\end{array}$ \\
\hline
\end{tabular}

by use of the Shapiro-Wilk test. Then, the relative accuracy of position $\sigma$ was determined using Eq. 1:

$\sigma=\sqrt{\frac{1}{n-1} a^{2}+b^{2}+c^{2}+x_{n}^{2}}$

where $\sigma$ is the standard deviation of the distances (a, b, c, .., $\mathrm{x}$ ) between selected vertices of cEst and, respectively, ATKISDLM polygons.

Based on the known position accuracy of the Base DLM as reference ( $\pm 3 \mathrm{~m}, \mathrm{HVBG} 2014$ ), the next step was to calculate the absolute accuracy $S$ of position according to Eq. 2:

$S=\sqrt{\sigma_{1}^{2}+\sigma^{2}}$

where $\sigma_{1}$ is the known absolute position accuracy of the reference data.

The accuracy of the map content was determined by use of a minimal sample $(n=20)$ of selected features (polygons depicting the spatial extension of a given ecosystem type) of the forest-type map of Germany (1:500,000 equivalent scale). Minimum sample size (MSS) was estimated according to Friedrichs (1990), which has to be considered as the absolute minimum for binary classifications (true, false), and not in the sense of a stratified sampling. These map features were compared with vegetation data collected within Hesse. This vegetation data comprise information from the official monitoring of FFH habitats in Hesse, the Hessian mapping of biotopes and the Hessian forest management. It was examined whether or not the forest type contained in the German-wide map can be corroborated as dominating or sub-dominating by respective information from the vegetation surveys in Hesse. In addition to the sample of 20 objects with a spatial extension, thematic accuracy was determined by a set of 364 German-wide, but punctual vegetation samplings (since 1990) from the database from the Institute of Forestry Eberswalde, Germany, used for a determination of the current forest ecosystem types at these locations (Jenssen et al. 2013).
cEsT in the Kellerwald National Park To derive a regional data of forest types with a spatial resolution equivalent to a map scale of $1: 25,000$, the following data from the regional vegetation surveys in the Kellerwald National Park were used according to the work flow depicted in Fig. 2: Map of cEst in Germany (1:500,000 equivalent scale), the basic vegetation survey of FFH-area No. 4819-301 "Kellerwald", the inventory of biotope types in Hesse, data collected for forest management, data concerning percentages of forest tree species and forest stand age, and vegetation data from ICP Forests Level II (plot 608).

Based on this information, a hypothetical forest-type pattern was derived by region-specific assignment rules considering Habitats Directive Annex I habitat types (HabT), information on the regional hypsometric and horizontal allocation of the potential natural ecosystem type (pEsT, 1:500,000), Hessian mapping of biotops (HB) and dominating tree species (DT) as preconditions and mapped which subsequently was evaluated by data from vegetation surveys (Meyer 2012; Schmidt 2010) and random sampling inspection conducted together with experts from the National Park authority (Table 2). For instance, all forests belonging to HabT 9110 (Luzulo-Fagetum beech forests) were assigned according their geographic and hypsometric location in terms of the Germany-wide forest classification (Jenssen et al. 2013; Schröder et al. 2015) as Moder beech forests of the montane level (D1-6d-C2) and Moder beech forests, lowland (Eb-5n-C2). Another example: 21.67 ha of the Kellerwald National Park is covered by HabT 91E0 "Alluvial forests with Alnus glutinosa and Fraxinus excelsior (AlnoPadion, Alnion incanae, Salicion albae)" or, respectively, HB code 01.173 "Riverside floodplain forests". Both were assigned to ecosystem type Dg-8z-D1 "Alluvial sycamore maple and black alder forests of the montane level", because the German-wide map reveals this ecosystem type as the most frequent alluvial forest type in the neighborhood of the Kellerwald National Park. Forests not displayed as a specific Habitats Directive Annex I habitat type were assigned according to the Hessian biotope classification and the Hessian forest management data on dominating tree species. 
Fig. 2 Workflow for mapping current ecosystem types of the National Park Kellerwald (Germany)

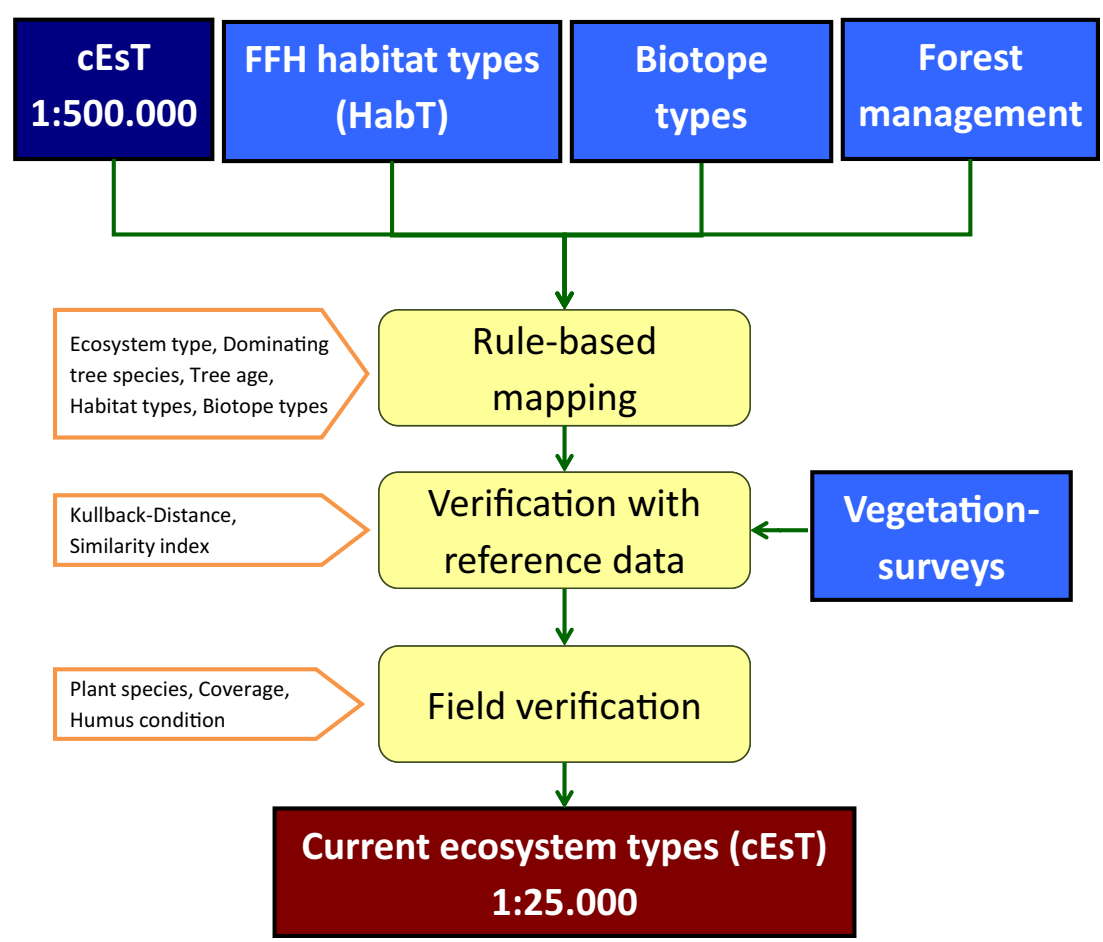

To account for the accuracy of the Kellerwald forest-type map, the accuracy of the content was evaluated according to ISO (2013) through relating it to site-specific vegetation surveys by the Kullback information (Jenssen 2010; Kullback 1951), extensively described by Schröder et al. (2017b). The methodological principle is based on: (1) comprehensive information on species composition and coverage degrees averaged out for each ecosystem type (reference state 1961-1990), (2) information on current species composition and coverage degrees at selected sites in the Kellerwald National Park ( $n=$ 105; 2007-2009, 2015), and (3) comparisons between the current state of the vegetation at these sites and the whole set of reference states, stored in the vegetation database from the Institute of Forestry Eberswalde (Germany). To this end, Kullback information was used as a statistical distance measure (Eq. 4), and the sum of coverage values of all species was normalised according to Eq. 5:

$K\left(p_{1}, . ., p_{s}, p_{1}^{o}, . . p_{s}^{o}\right)=\sum_{i=1}^{S} p_{i} \operatorname{In}\left(\frac{p_{i}}{p_{i}^{o}}\right)$

where $p i=$ abundance of plant species (i) as well as soil covering moss and lichen species, and $p_{1}^{o}=$ average abundance of these species on all plots assigned to a specific forest type (1961-1990):

$\sum_{i=1}^{S} p_{i}=1$

(4) Referring to the ecosystem type-specific reference states, species composition at sites of the vegetation survey was assigned to that forest type, for which the lowest Kullback distance (Eq. 4) could be calculated. This was performed for the whole sample in the Kellerwald National Park $(n=105)$. (5) Thematic accuracy according to ISO (2013) was quantified by comparing the map of cEsT with site specific information on cEst.

Finally, the misclassifications found were used to fit the rule-based map of cEsT in the Kellerwald to the validation data (Fig. 3). In particular, the whole border between ecosystem types of the lowland level and ecosystem types of the montane level was shifted southeast.

\section{Access to data and metadata description}

Nickel et al. (2018). Formats: .ZIP file with geodata (ESRI Shapefile) and tabular data (CSV). The associated metadata are accessible at https://agroenvgeo.data.inra.fr/geonetwork/ srv/fre/catalog.search\#/metadata/b5e5d76f-6176-4d6d-9089a607bc8a4076.

\section{Technical validation}

The map of current forest ecosystem types (cEsT) in Germany (1:500,000 equivalent scale) has an absolute positional accuracy of $\pm 42.29 \mathrm{~m}(\approx \pm 42 \mathrm{~m})$. It has been classified correctly to approx. 30\%. A further approx. $35 \%$ are ecologically similar to the existing forest ecosystem types (together 65\%). In a further approx. $15 \%$, the 
Table 2 Rule base for deriving spatial information on current ecosystem types from available data on the Kellerwald National Park

\begin{tabular}{|c|c|c|c|c|c|}
\hline \multicolumn{4}{|c|}{ Preconditions } & \multicolumn{2}{|l|}{ Conclusion } \\
\hline HabT & HB & pEsT & DT & cEsT & cEsT description \\
\hline \multicolumn{6}{|c|}{ 1. Near- and semi-natural ecosystem types } \\
\hline 9110 & & D1, Dg & & D1-5n-C2 & Moder beech forests of the montane level \\
\hline 9110 & & D1, Dg & & $\mathrm{Eb}-5 \mathrm{n}-\mathrm{C} 2$ & Moder beech forests \\
\hline 9130 & & D1, Dg & & $\begin{array}{l}\text { Eb-5n-D1 } \\
\text { Eb-5n-D1a }\end{array}$ & $\begin{array}{l}\text { Loamy Brown mull beech forests } \\
\text { Sandy brown mull beech forests }\end{array}$ \\
\hline 9130 & & D1, Dg & & $\begin{array}{l}\text { D1-6d-D1 } \\
\text { D1-6d-E1 }\end{array}$ & $\begin{array}{l}\text { Brown mull beech forests of the montane level } \\
\text { Mull beech forests of the montane level }\end{array}$ \\
\hline 9160 & 01.150 & & & $\begin{array}{l}\text { Eg-7 g-C1 } \\
\text { Eg-7g-D1 }\end{array}$ & $\begin{array}{l}\text { Hygrophilous Moder common oak and hornbeam forests } \\
\text { Hygrophilous brown mull common oak and hornbeam forests }\end{array}$ \\
\hline 9170 & 01.150 & & & Eg-2r-E2 & Thermophilous sessile oak forests on rocks \\
\hline $9180 *$ & 01.162 & & & Eg-5r-E1 & Wych elm and large-leaved lime block forests \\
\hline \multirow[t]{2}{*}{$91 \mathrm{E} 0 *$} & 01.173 & & & Dg-8z-D1 & $\begin{array}{l}\text { Alluvial sycamore maple and black alder forests of the } \\
\text { montane level }\end{array}$ \\
\hline & 01.142 & & & $\mathrm{Eg}-7 \mathrm{~g}-\mathrm{C} 1$ & Hygrophilous Moder common oak and hornbeam forests \\
\hline \multicolumn{6}{|c|}{ 2. Cultivated ecosystem types } \\
\hline & 01.183 & $\mathrm{~Eb}, \mathrm{Eg}$ & Oak & Eg-5n-c1 & Moder oak forests \\
\hline & 01.220 & $\mathrm{~Eb}, \mathrm{Eg}$ & & Eg-5n-c2 & Moder spruce forests \\
\hline & 01.220 & D1, Dg & & Dg-5n-c2 & Moder spruce forests of the montane level \\
\hline & 01.220 & $\mathrm{~Eb}, \mathrm{Eg}$ & Pine & $\mathrm{Eb}-4 \mathrm{n}-\mathrm{c} 2$ & Moder pine forests \\
\hline & 01.220 & D1, Dg & & Dg-5n-b1 & Raw humus spruce forests of the montane level \\
\hline & 01.300 & $\mathrm{~Eb}, \mathrm{Eg}$ & Oak & Eg-5n-c1 & Moder oak forests \\
\hline & 01.300 & D1, Dg & & Dg-5n-c2 & Moder spruce forests of the montane level \\
\hline & 01.300 & $\mathrm{~Eb}, \mathrm{Eg}$ & & Eg-5n-c2 & Moder spruce forests \\
\hline & 01.300 & $\mathrm{~Eb}, \mathrm{Eg}$ & Pine & Eb-4n-c2 & Moder pine forests \\
\hline & 01.300 & $\mathrm{~Eb}, \mathrm{Eg}$ & Larch & Eg-4n-b1 & Raw humus larch forests \\
\hline
\end{tabular}

HabT, Habitats Directive Annex I habitat types $9110=$ Luzulo-Fagetum (beech forests); $9130=$ Asperulo-Fagetum beech forests; $9160=$ Sub-Atlantic and medio-European oak or oak-hornbeam forests of the Carpinion betuli; $9170=$ Galio-Carpinetum oak-hornbeam forests; $9180 *=$ Tilio-Acerion forests of slopes, screes and ravines; 91E0* = Alluvial forests with Alnus glutinosa and Fraxinus excelsior (Alno-Padion, Alnion incanae, Salicion albae) $H B$, Hessian mapping of biotops $01.150=$ oak forests; $01.162=$ other hardwood forests; 01.173 = riverside floodplain forests; $01.142=$ other oakhornbeam forests; 01.183 = other cultivated deciduous forests; $01.220=$ other coniferous forests; $01.300=$ mixed forests;

$p E s T$, regional hypsometric and horizontal allocation of the potential natural ecosystem type (pEsT, 1:500,000): Eb = sub-Atlantic lowlands; Eg = lowlands (general); D1 = montane level (without conifers); $\mathrm{Dg}=$ montane level (general);

$D T$, Hessian forest management data on dominating tree species

ecosystem types were correctly classified, but only appeared as non-dominant ecosystem types. Approximately $15 \%$ occurred only as an ecologically similar cEsT (together 30\%). Five percent of the spatial objects were mapped incorrectly. The area of the polygons ranges between 2,500 $\mathrm{m}^{2}$ and $476.5 \mathrm{~km}^{2}$.

Since the validation data was used for a revision of the rulebased map (e.g. the border between ecosystem types of the lowland level and ecosystem types of the montane level was shifted southeast), the thematic correctness of the cEst in the Kellerwald National Park (1:25,000 equivalent scale) is only valid with regard to purely rule-based map. Before fitting the map to the validation data, about $22 \%$ of the cEsT were classified correctly. The range of the polygon areas is between 50 $\mathrm{m}^{2}$ and $0.68 \mathrm{~km}^{2}$

\section{Reuse Potential and Limits}

Misclassifications on both scales were often due to wrong assignments to the altitude level (e.g. Eb-5n-C2 with $\mathrm{Eb}=$ lowland level instead of D1-5n-C2 with D1 = montane level) and, respectively, to the humus form (e.g. Eb-5n-D1 with D1 = loamy brown mull instead of Eb-5n-D1a with D1a = sandy brown mull). The main reason for misclassifications must be seen in high thematic differentiation of the ecosystem classification according to Jenssen et al. (2013). In the Kellerwald National Park, wrong classifications refer in particular to Moder pine forests (Eb-4n-c2) and to Moder spruce forests (Eb-4n-c2, Eg-5n-c2) due to uncertain data on dominating tree species and extreme local conditions. The rule base for deriving cEsT in the Kellerwald is not applicable under different conditions, meaning 


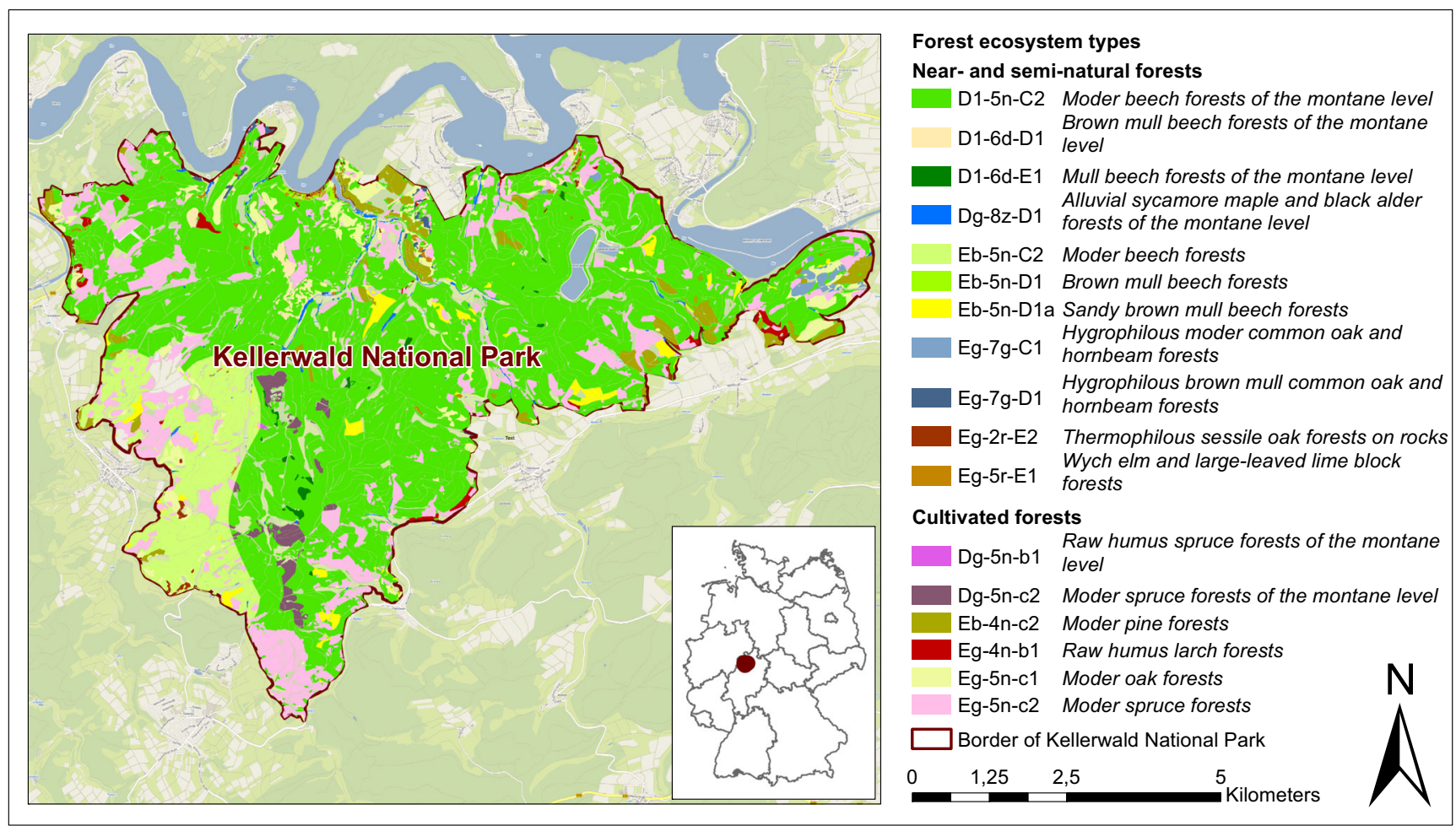

Fig. 3 Map of current forest ecosystem types (cEsT) in the Kellerwald National Park

that for each other investigation area, a specific rule base has to be defined adapted to available data. On this spatial scale, it is also recommended to use additionally the key for identifying forest ecosystems in Germany (Hofmann 2017). With regard to the positional accuracy of the German-wide map, it has to be considered that, due to data availability, validation data with known positional accuracies were exclusively located in Hesse, limiting the representativity for the whole territory of Germany.

Funding The investigation was funded by the German Environment Agency (Umweltbundesamt, Dessau-Roßlau, Germany)

\section{Compliance with ethical standards}

Conflict of interest The authors declare that they have no conflict of interest.

\section{References}

EEA (European Environment Agency) (2010) Corine Land Cover 2000 raster data $(100 \mathrm{~m} \mathrm{x} 100 \mathrm{~m})$. https://www.eea.europa.eu/data-andmaps/data/clc-2000-raster (28.07.2011)

EFDAC (European Forest Data Center) (2011) Species distribution - tree species maps - dominant species distribution $(1 \mathrm{~km} \mathrm{x} 1 \mathrm{~km}$, year 2000). http://forest.jrc.ec.europa.eu/download/data/speciesdistribution/ (02.10.2011)

Friedrichs J (1990) Methoden empirischer Sozialforschung, 14. Auflage. Westdeutscher Verlag, Opladen
Hofmann G (1997) Mitteleuropäische Wald- und Forstökosystemtypen in Wort und Bild, 2nd edn. AFZ - Der Wald. Dt Landwirtschvlg 2. erw Aufl, München, pp 1-85

Hofmann G (2017) Bestimmungsschlüssel der Wald- und Forstökosystemtypen Deutschlands. Forschungskennzahl (UFOPLAN) 371383 254. Dessau, Vechta, 184 S.

HVBG (2014): Digitales Basis-Landschaftsmodell (Basis-DLM) von Hessen. Hessische Verwaltung für Bodenmanagement und Geoinformation. http://www.hvbg.hessen.de. Accessed 11 June 2019

ISO (2013) Geographic information - Data quality (EN ISO 19157), English version, 2014-04.

Jenssen M (2010): Modellierung und Kartierung räumlich differenzierter Wirkungen von Stickstoffeinträgen in Ökosysteme im Rahmen der UNECE-Luftreinhaltekonvention. Teilbericht IIII: Modellierung der Wirkung der Stickstoff-Deposition auf die biologische Vielfalt der Pflanzengesellschaften von Wäldern der gemäßigten Breiten. UBATexte 09/2010. Dessau-Roßlau:1-50

Jenssen M, Hofmann G, Nickel S, Pesch R, Riediger J, Schröder W (2013): Bewertungskonzept für die Gefährdung der Ökosystemintegrität durch die Wirkungen des Klimawandels in Kombination mit Stoffeinträgen unter Beachtung von Ökosystemfunktionen und -dienstleistungen. Umweltforschungsplan des Bundesministeriums für Umwelt, Naturschutz und Reaktorsicherheit. Forschungsvorhaben 371083 214, UBA-FB 001834. UBA-Texte 87/2013. Dessau, Textband +9 Anhänge: $381 \mathrm{~S}$. https://www.umweltbundesamt.de/sites/default/files/ medien/378/publikationen/texte_87_2013_bewertungskonzept_fuer die_gefaehrdung_der_oekosystemintegritaet_durch_die_wirkungen des klimawandels.pdf. Accessed 03 September $201 \overline{-}$

Kullback S (1951) Information theory and statistics. Wiley, New York

Meyer P (2012) Auf dem Weg zum Naturwald. Standortbestimmung des Nationalparks Kellerwald-Edersee auf Grundlage der permanenten Stichprobeninventur 2007-2009. 3. Hessisches Naturwaldforum Buche, 5-6-Mai 2010, Bad Wildungen, Proceedings:11-14 
Nickel S, Schröder W, Jenssen M (2018) Semi-natural forest ecosystem types of Germany and the Kellerwald National Park (Hesse, Germany), link to files. Version 24 May 2019. PANGAEA. [Dataset]. https://doi.org/10.1594/PANGAEA.887305

Schmidt M (2010): Wie naturnah und artenreich ist die Waldvegetation? Allgemeine Forstzeitschrift, AFZ Der Wald, 17/2010

Schröder W, Nickel S, Jenssen M, Riediger J (2015) Methodology to assess and map the potential development of forest ecosystems exposed to climate change and atmospheric nitrogen deposition: a pilot study Germany. Sci Total Environ 521-522:108-122

Schröder W, Nickel S, Jenssen M, Hofmann G, Schlutow A, Nagel HD, Burkhard B, Dworczyk C, Elsasser P, Lorenz M, Meyerhoff J, Weller P, Altenbrunn K (2017a): Anwendung des Bewertungskonzepts für die Ökosystemintegrität unter Berücksichtigung des Klimawandels in Kombination mit
Stoffeinträgen. Abschlussbericht Forschungskennzahl (UFOPLAN) 371383 254. Dessau, Vechta.

Schröder W, Nickel S, Jenssen M, Hofmann G (2017b): Anleitung zur Beurteilung der Integrität von Wald- und Forstökosystemen in Deutschland. Forschungskennzahl (UFOPLAN) 371383254. Dessau, Vechta.

Suck R, Bushart M, Hofmann G, Schröder L, Bohn U (2010) Karte der Potentiellen Natürlichen Vegetation Deutschlands: Band 1. Maßstab 1 : 500.000; Karten + Legende. BfN-Schriftenvertrieb im Landwirtschaftsverlag Münster. Kartenteil: 7 Karten; Legende: 1-24.

Publisher's note Springer Nature remains neutral with regard to jurisdictional claims in published maps and institutional affiliations. 